\title{
Cuscuta campestris Yunck. (Convolvulaceae): new addition to the alien flora of Assam, India
}

\author{
Barnali Das \& Namita Nath* \\ Department of Botany, Gauhati University, Guwahati, 781 014, India \\ *Email: nathnamita1@gauhati.ac.in
}

\section{OPEN ACCESS}

\section{ARTICLE HISTORY}

Received: 01 November 2021

Accepted: 16 January 2022

Available online

Version 1.0: 21 February 2022

\section{Check for updates}

\section{Additional information}

Peer review: Publisher thanks Sectional Editor and the other anonymous reviewers for their contribution to the peer review of this work.

Reprints \& permissions information is available at https://horizonepublishing.com/ journals/index.php/PST/open_access_policy

Publisher's Note: Horizon e-Publishing Group remains neutral with regard to jurisdictional claims in published maps and institutional affiliations.

Indexing: Plant Science Today, published by Horizon e-Publishing Group, is covered by Scopus, Web of Science, BIOSIS Previews, Clarivate Analytics, etc. See https:// horizonepublishing.com/journals/index.php/ PST/indexing_abstracting

Copyright: $\odot$ The Author(s). This is an openaccess article distributed under the terms of the Creative Commons Attribution License, which permits unrestricted use, distribution and reproduction in any medium, provided the original author and source are credited (https://creativecommons.org/licenses/ by/4.0/)

\section{CITE THIS ARTICLE}

Das B, Nath N. Cuscuta campestris Yunck. (Convolvulaceae): new addition to the alien flora of Assam, India. Plant Science Today. 2022;9(sp1):5-8. https://doi.org/10.14719/ pst. 1580

\begin{abstract}
Cuscuta campestris Yunck. is a well known holoparasitic angiosperm of the family Convolvulaceae. Here, this species is reported as a new addition to the alien Flora of the Assam state. Detailed taxonomic description has been given along with relevant information and colour photographs for its correct identification.
\end{abstract}

\section{Keywords \\ Assam, Convolvulaceae, Cuscuta campestris, flora, new addition}

\section{Introduction}

The Genus Cuscuta L. is well known for its parasitic members. Earlier it was included in the family Cuscutaceae, but from recent phylogenetic works and molecular analysis this genus has been shifted to the family Convolvulaceae (1). There are about 200 parasitic species of the genus (2); they are distributed throughout the temperate, tropical and sub-tropical regions of the world, Americas being the centres of diversity (3). All the species of the genus Cuscuta are usually achlorophyllous, rootless obligate parasites with reduced vegetative characters. These leafless parasitic species are only minimally photosynthetic, and totally dependent on their host (4). But interestingly they are found to self-parasitize as well as hyper-parasitize (5). The members of the genus Cuscuta reported to show homoplasy for morphological characters, like nature of dehiscence of fruit (6), features of pollen (7) and some characteristics of gynoecium (8).

In India there are about 7 species documented in Flora of British India (9). Cuscuta campestris Yunck. was reported first time for India from West Bengal (10). Subsequently, this species was also reported from various states of India like Madhya Pradesh (11), Uttar Pradesh (12,13), Jammu and Kashmir (14), Tamil Nadu (15), Meghalaya (16) etc. In Assam only Cuscuta reflexa Roxb. has been reported till date; and this forms the first report of $C$. campestris from the state.

Out of 7 species of Cuscuta all over the country, in the state of Assam, single species i.e. C. reflexa has been reported and studied extensively so far. But surprisingly there is no report of the extensively spreading invasive parasite $C$. campestris or the Golden dodder plant from Assam in important floristic literatures (17-19) of the region till now. Like C. reflexa, it shows self parasitism. This parasitic plant generally attacks herbaceous plants and trees of young stages. 


\section{Materials and Methods}

Floristic survey was done consecutively for 2 years (20192021) for M. Phil degree of the first author. During that period, the authors observed a parasitic angiosperm infecting a wide range of host at various locations of districts like Kamrup (M), Barpeta, Nalbari, Morigaon etc. of Assam, India. The specimen was identified with the help of taxonomic literature and through virtual herbarium provided by KEW (K000195797, digital image!). A voucher specimen (BD0016) was prepared by following the standard method (20) and submitted at GUBH. For palynological studies, pollens were collected and dried properly; after that SEM images were taken and measurements were recorded.
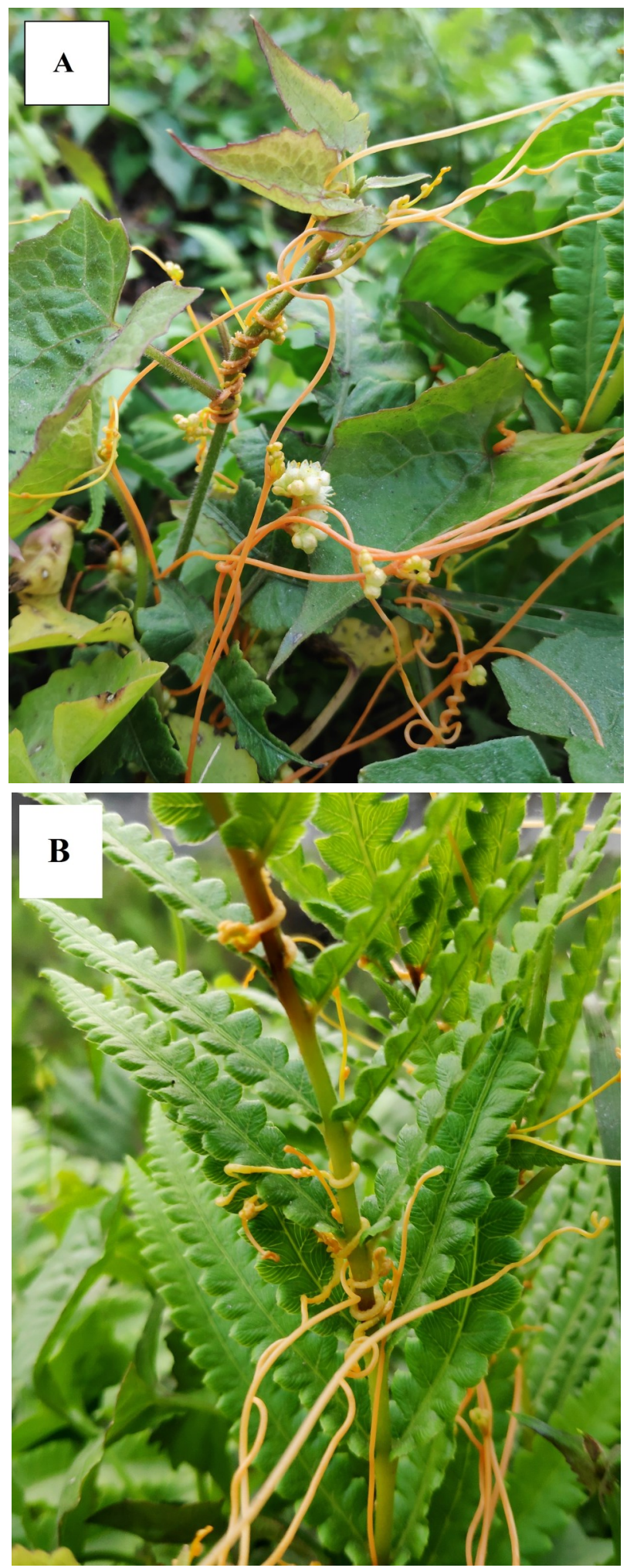
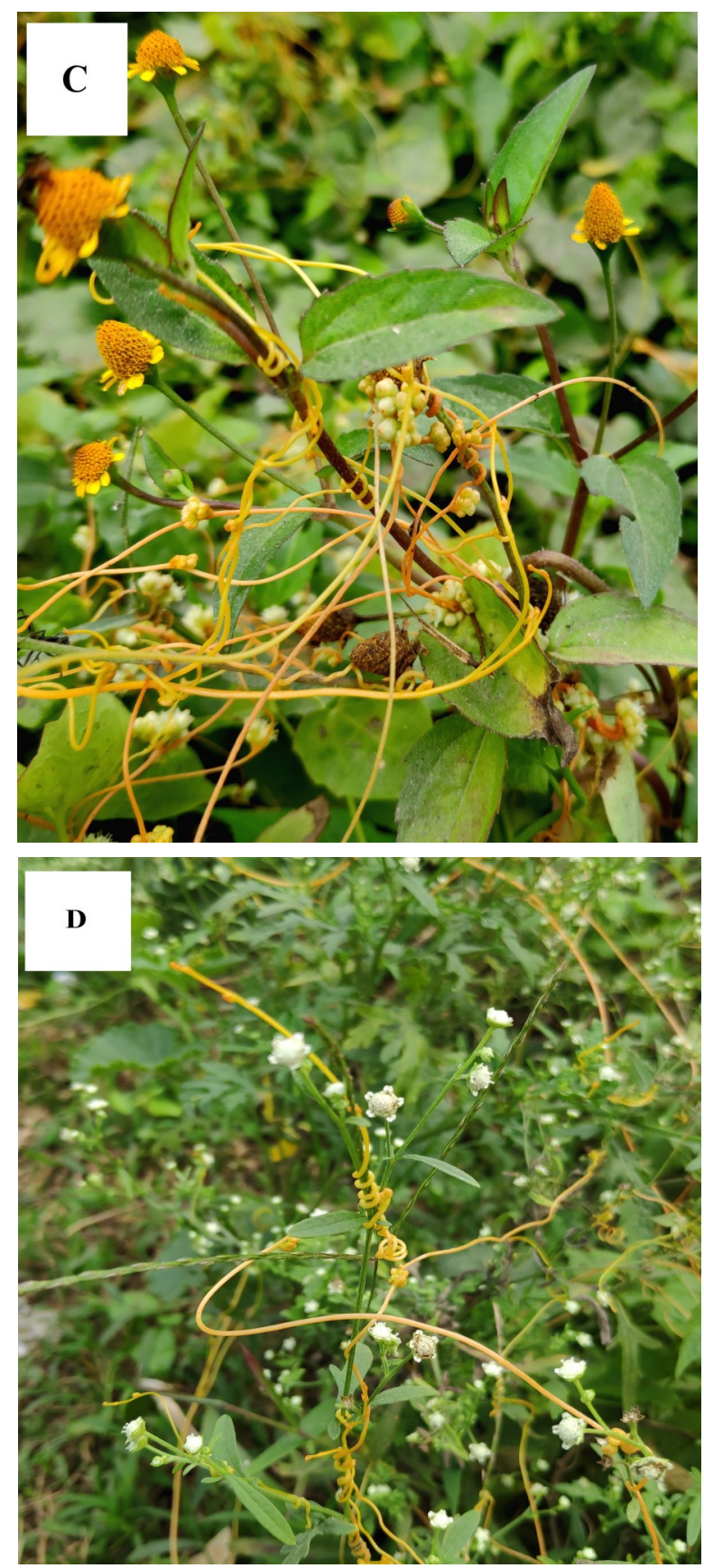

Fig. 1. Cuscuta campestris with four different hosts; A. Mikania micrantha, B. Christella dentata, C. Acmella paniculata, D. Parthenium hysterophorus.

\section{Taxonomic description}

\section{Cuscuta campestris}

Yunck. in Mem. Torrey Bot. Club 18: 138. 1932; Mill in D.G. Long \& Grierson, Fl. Bhutan 2(2): 864, 1999.

Achlorophyllous, leafless, twining much branched obligate stem parasite; stem ca. $0.7 \mathrm{~mm}$ in diameter, slender, very thin, yellow to light orange in colour, usually leafless or reduced to scale-like structures; inflorescence compactly clustered, lateral, 15-22-flowered, umbelliform; shortly peduncled,1.4-2.0 mm long; Flower sessile or with short pedicel, actinomorphic, bisexual, whitish; bracts ca. $0.5 \mathrm{~mm}$ in length, light brownish, scaly; calyx cupular, 1.3$1.8 \mathrm{~mm}$ in length, gamosepalous, persistent, imbricate, 5lobed, glandular, light green to creamish in colour, apex obtuse, outer surface ridged; corolla $1.5-2.6 \times 0.4-0.8 \mathrm{~mm}$ in size, campanulate, gamopetalous, persistent, whitish to 
cream in colour, 5-lobed, apex often inflexed, corolla tube ca. $1.1 \mathrm{~mm}$ long; infrastaminal scales ca. $0.6 \mathrm{~mm}$ long, fimbriate above, reaching up to stamens, base ovate; stamens persistent 0.4-0.6 $\mathrm{mm}$ long, epipetalous, filaments subulate, broad at base and gradually tapered towards apex, anthers $0.2-0.3 \mathrm{~mm}$ in length, yellow, ovoid-oblong, pollens colpate; gynoecium 1.8-2 mm long, ovary globose, style 2, filiform, stigma capitate ca. $0.2 \mathrm{~mm}$ long; capsule ca. 2.8 $\mathrm{mm}$ in diameter, membranous, subtended by withered corolla and calyx, irregularly dehiscent; seeds 2-4 per fruit, 1$1.5 \mathrm{~mm}$ in diameter, edospermous, flattened at one side, scabrous, brownish.

\section{Flowering \& fruiting}

Throughout the year.

\section{Vernacular Names}

Akashilata, Amarlata, Swarnalata (Assamese); Golden dodder (English).

\section{Habitat}

A parasitic angiosperm found mostly in association with herbaceous plants.

\section{Distribution}

Native to Neartic region but introduced in other parts of the world including India.

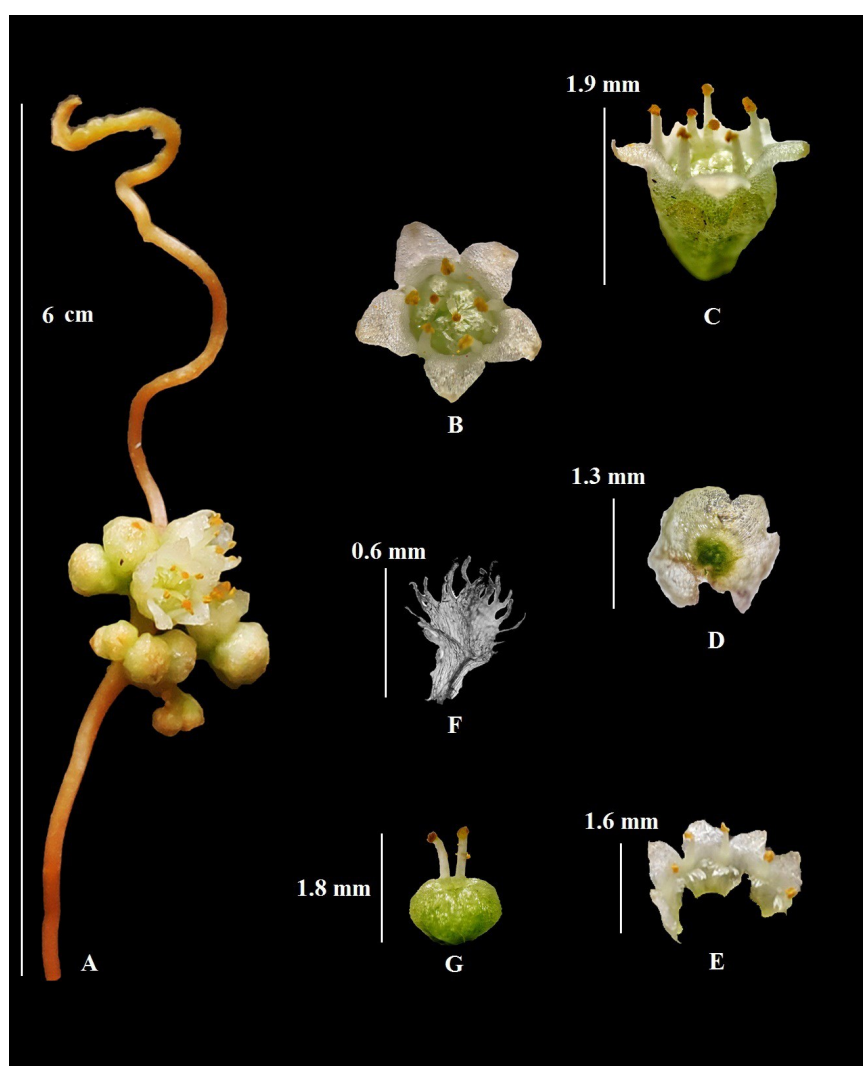

Fig. 2. Cuscuta campestris: A. twig with capitate inflorescence; B. flower (top view); C. complete flower (side view); D. calyx; E. corolla with epipetalous stamens; F. infrastaminal scale; G. gynoecium.

\section{Palynology}

Polarity- Isopolar, Outline- Oval, Aperture type- Colpate; Pollen Class- Mediae; Number of Apertures- 3/4; Pollen unit - Monad ; Polar diameter- $27.34 \mu \mathrm{m}$; Equatorial diameter$24.43 \mu \mathrm{m} ; \mathrm{P} / \mathrm{E}$ ratio- 1.12; Pollen shape: Prolate- spheroidal; Exine ornamentation- Microechinate with blunt ends.
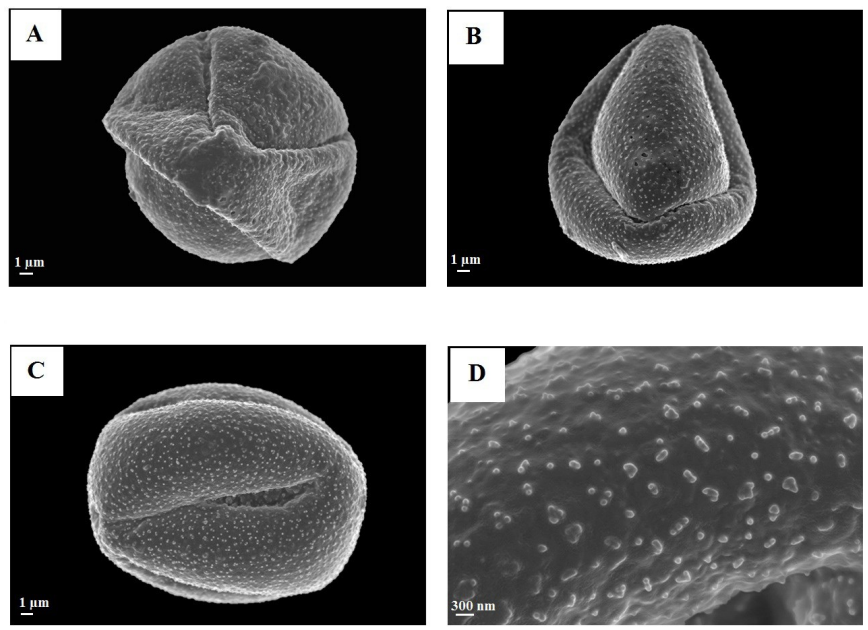

Fig. 3. Pollen of Cuscuta campestris; A, B, C. Single pollen unit from different angles, D. Exine ornamentation.

\section{Significance of the study}

Cuscuta campestris is an invasive obligate parasite which is going to bring a devastating threat to the native flora of Assam. It was not recorded in any floristic literature of the region (9-11) earlier because of misidentification as C. reflexa due to the morphological similarities. The morphological differences between these 2 species are tabulated in Table 1 (22). This study will help to bring attention to the scientific community to control its rapid spread across the state.

Table 1. Morphological comparison between C. campestris and C. reflexa

\begin{tabular}{|c|c|c|}
\hline Characters & C. campestris & C. reflexa \\
\hline Plant body & $\begin{array}{l}\text { Much entangled, comparatively } \\
\text { tough }\end{array}$ & Slender and delicate \\
\hline Stem & $\begin{array}{l}\text { Thin, bright orange to yellow in } \\
\text { colour }\end{array}$ & $\begin{array}{l}\text { Thick, yellowish green to } \\
\text { light green in colour }\end{array}$ \\
\hline Flower & Flowers born in clusters, small & $\begin{array}{l}\text { Few flowers in cluster, com- } \\
\text { paratively large }\end{array}$ \\
\hline $\begin{array}{l}\text { Infrastami- } \\
\text { nal scale }\end{array}$ & $\begin{array}{l}\text { As long as corolla tube, oblong } \\
\text { in shape }\end{array}$ & $\begin{array}{l}\text { Reaching middle of the } \\
\text { corolla tube, ovate }\end{array}$ \\
\hline Style & Style 2, filiform & Style 1 , very short or absent \\
\hline Stigma & Stigma capitate or globose & Stigma ligulate \\
\hline
\end{tabular}

\section{Specimen examined}

India, Assam, Kamrup Metro district, Jalukbari; $26^{\circ} 09^{\prime} 13.7^{\prime \prime}$ N 91 39'35.8” E, 04 December 2020, Barnali Das BD0016 (GUBH!).

\section{Acknowledgements}

The authors are grateful to the Board of Trustees, Royal Botanic Gardens, Kew; Dr. Souravyoti Borah, Curator, Gauhati University Botanical Herbarium (GUBH) and Rakesh Talukdar of Dept. of Chemistry, Gauhati University.

\section{Authors contributions}

BD \& NN have prepared the manuscript for correspondence. BD had collected and identified the plant. Both authors read and approved the final manuscript. 


\section{Compliance with ethical standards}

Conflict of interest: The authors have no competing interests.

Ethical issues: None.

\section{References}

1. Angiosperm Phylogeny Group. An update of the Angiosperm Phylogeny Group classification for the orders and families of flowering plants: APG IV. Botanical Journal of the Linnean Society. 2016;181:1-20. https://doi.org/10.1111/boj.12385

2. Mabberley DJ. Mabberley's Plant-Book: A portable dictionary of plants, their classification and uses. $4^{\text {th }}$ edition. Cambridge: Cambridge University Press; 2017. p. 260. https:// doi.org/10.1017/9781316335581

3. Yuncker TG. The genus Cuscuta. Memoirs of the Torrey Botanical Club. Vol. 18. Kew: The Royal Botanic Gardens; 1932. p. 113-331. https://www.biodiversitylibrary.org/page/41775377

4. Kelly CK. Resource choice in Cuscuta europaea. The Proceedings of the National Academy of Sciences. 1992; 89:12194-97. https:// doi.org/10.1073/pnas.89.24.12194

5. Hong L, Shen H, Chen H, Li L, Hu XY, Xu XL et al. The morphology and anatomy of the haustoria of the holoparasitic angiosperm Cuscuta campestris. Pakistan Joumal of Botany. 2011; 43(4):1853-1859. http://www.pakbs.org/ pjbot/PDFs/43(4)/PJB43(4)1853.pdf

6. Stefanovic S, Kuzmina M, Costea M. Delimitation of major lineages within Cuscuta subgenus Grammica (Convolvulaceae) using plastid and nuclear DNA sequences. American Journal of Botany. 2007;94:568. http://dx.doi.org/10.3732/ajb.94.4.568

7. Welsh M, Stefanovic S, Costea M. Pollen evolution and its taxonomic significance in Cuscuta (dodders, Convolvulaceae). Plant Systematics and Evolution. 2010;285:83-101. http:// dx.doi.org/10.1007/s00606-009-0259-4

8. Wright MAR, Welsh M, Costea M. Diversity and evolution of the gynoecium in Cuscuta (Convolvulaceae) in relation to their reproductive biology: two styles are better than one. Plant Systematics and Evolution. 2011;296:51-76. http://dx.doi.org/10.1007/ s00606-011-0476-5

9. Clarke CB. Convolvulaceae. In: Hooker JD, editor. Flora of British India, Vol. 4.L. England: Reeve and Co Ltd; 1883.p.4: 179-228.
10. Santapau H, Korlahalli BC. Cuscuta campestris Yuncker - A new record for India. The Journal of the Bombay Natural History Society. 1966;62:598-99.

11. Mishra JS, Moorthy BTS, Bhan M. Efficacy of herbicides against field dodder (Cuscuta campestris) in lentil, chickpea and linseed. Indian Journal of Weed Science. 2005; 37(3-4): 220-24.

12. Kaur J, Narain S, Kumar S. Novelties in Convolvulaceae to the Flora of Allahabad District (Uttar Pradesh, India). Bionature. 2018; 38(4): 259-65. https://doi.org/10.13140/RG.2.2.20033.45928

13. Ansari AA, Tiwari AP. Phytodiversity of Ranipur Wildlife Sanctuary, Uttar Pradesh. Journal of Economic and Taxonomic Botany. 2013;37(1):130-86.

14. Bhellum BL, Mangotra R. Cuscuta campestris Yuncker - A new record for the flora of Jammu and Kashmir. Indian Journal of Forestry. 1996;19(1):103-04.

15. Srinivasan SR. Cuscuta campestris Yuncker (Cuscutaceae) - A new record for South India. Bulletin of Botanical Survey of India.1973;15(1-2):160.

16. Bhat NA, Jeri L, Kumar Y, Mir AH. First observation of field dodder and its host range in Meghalaya. Indian Journal of Weed Science. 2018;50(2):192-94. https://doi.org/10.5958/0974-8164.2018.00046.1

17. Kanjilal UN, Kanjilal PC, Das A, De RN. Flora of Assam, Vol. 4. Shillong: Govt. of Assam Press; 1940. p. 362.

18. Choudhury $\mathrm{S}$, et. al. Assam's Flora (Present status of Vascular Plants). Guwahati, Assam : ASTEC, Bigyan Bhawan; 2005. p. 246.

19. Barooah C, Ahmed I. Plant Diversity of Assam: A Checklist of Angiosperms and Gymnosperms. Guwahati, Assam: Assam Science Technology and Environmental Council; 2014. p. 255.

20. Jain SK, Rao RR. A Handbook of Field and Herbarium Methods. New Delhi, India: Today and Tomorrow's Printers and Publishers; 1977.p.1-150.

21. Mill RR. Cuscutaceae. In: Long DG, Grierson AJC, editors. Flora of Bhutan, Vol. 2(2). Edinburgh: Royal Botanic Gardens; 1999. p. 864.

22. Mishra JS. Biology and Management of Cuscuta species. Indian Journal of Weed Science. 2009;41(1-2):1-11.

$\S \S \S$ 